$1-1988$

\title{
G. H. Mead, Socialism, and the Progressive Agenda
}

Dmitri N. Shalin

University of Nevada, Las Vegas, shalin@unlv.nevada.edu

Follow this and additional works at: https://digitalscholarship.unlv.edu/sociology_pubs

Part of the Politics and Social Change Commons, Social Psychology and Interaction Commons, and the Sociology of Culture Commons

\section{Repository Citation}

Shalin, D. N. (1988). G. H. Mead, Socialism, and the Progressive Agenda. American Journal of Sociology, 93(4), 913-951.

https://digitalscholarship.unlv.edu/sociology_pubs/48

This Article is protected by copyright and/or related rights. It has been brought to you by Digital Scholarship@UNLV with permission from the rights-holder(s). You are free to use this Article in any way that is permitted by the copyright and related rights legislation that applies to your use. For other uses you need to obtain permission from the rights-holder(s) directly, unless additional rights are indicated by a Creative Commons license in the record and/ or on the work itself.

This Article has been accepted for inclusion in Sociology Faculty Publications by an authorized administrator of Digital Scholarship@UNLV. For more information, please contact digitalscholarship@unlv.edu. 


\title{
G. H. Mead, Socialism, and the Progressive Agenda ${ }^{1}$
}

\author{
Dmitri N. Shalin \\ Southern Illinois University at Carbondale
}

\begin{abstract}
Mead is known today primarily for his original philosophy and social psychology. Much less familiar to us is Mead the reformer, a man who sought to balance political engagement with academic detachment and who established himself as an astute critic of contemporary American society. This paper examines Mead's political beliefs and his theory of the reform process. Drawing on littleknown sources and archival materials, it demonstrates that Mead shared socialism's humanitarian ends and that, following the dominant progressive ideology of his time, he sought to accomplish these ends by constitutional means. An argument is made that Mead's ideological commitments had profound effects on his substantive ideas, particularly on the dialectical premises of social interactionism. The final section of the paper discusses the legacy of Mead and the Progressive movement.
\end{abstract}

The image of Mead many sociology students form in the years of their apprenticeship is that of an armchair philosopher, dispassionately discoursing on the nature of mind, self, and society and largely removed from the practical concerns of the day. It is usually later that they learn that Mead was at the forefront of the contemporary movement for social reform and at some point seriously contemplated a career as professional reformer. The publications by Diner (1975, 1980), Deegan and Burger (1978), and, more recently, Joas (1985) alert us to this less known facet of Mead's life. The extent of Mead's involvement in the Progressive move-

\begin{abstract}
1 This paper is part of a project on Progressivism and Chicago Sociology supported by a grant from the American Sociological Association's Committee on the Problems of the Discipline. The second section of the paper was presented at the annual meeting of the Midwest Sociological Society, Des Moines, 1986. I wish to thank my colleagues at Southern Illinois University for the generous responses they gave me during the discussion of this paper at the departmental seminar; Norbert Wiley for directing me to Mead's early publications in the Oberlin Review; Janet S. Belcove-Shalin for her help in deciphering some intractable passages from Mead's correspondence, as well as for her substantive comments; and three anonymous reviewers for their constructive criticism. Requests for reprints should be sent to Dmitri N. Shalin, Department of Sociology, Southern Illinois University at Carbondale, Carbondale, Illinois 62901.
\end{abstract}

(c) 1988 by The University of Chicago. All rights reserved.

0002-9602/88/9304-0006\$01.50 
ment and, more important, the effect it had on his social theory, however, are still far from being fully appraised.

One reason Mead's political views and engagements have until recently escaped close scrutiny is that the relevant publications (some unmentioned in any standard bibliography) appeared mostly in limited-circulation magazines and local newspapers, while a portion of his political writings-notably on socialism and the human cost of industrialization-were never published and are available only in manuscript form. ${ }^{2}$ The impression one draws from these writings, reinforced by Mead's private correspondence, is that of a man of radically democratic convictions, keenly aware of social inequality, and deeply concerned with the effect of the division of labor on the working man. Like many other progressives of his time, Mead was engaged in a lifelong polemic with socialists. He accepted without reservation their humanitarian ends but took issue with them on the question of means, fully embracing the basic progressivist tenet that the historically unique framework of American democracy provides the best available leverage for social reconstruction. Mead's life can be seen as an attempt to prove in both theory and practice that revolutionary objectives can be achieved by essentially conservative means.

This paper examines Mead's political beliefs and his theory of social reform. It also argues that Mead's substantive thought, and particularly the dialectical premises of social interactionism, reflected his ideological commitments. An auxiliary aim of this paper is to show that, even though progressive thinkers might have failed to answer the question of how to effect radical social change by working within the constitutional framework of democracy, they deserve credit for placing this question on the political agenda and stressing the public's role as an agent of social reconstruction.

I begin with the sociohistorical context of the Progressive movement. After tracing Mead's path to Progressivism, I analyze his theory of the reform process. Next, I explore the relationships between his political beliefs and substantive ideas. And finally, I discuss the contribution of Mead and the progressives to the theory and practice of American democracy.

\section{THE SOCIOHISTORICAL CONTEXT OF PROGRESSIVISM}

We plow new fields, we open new mines, we found new cities; we drive back the Indian and exterminate the buffalo; we girdle the land with iron

${ }^{2}$ One should also bear in mind that the articles by Mead gathered in a widely used volume edited by Reck (1964) sometimes appear there in an abridged form and that typically left out are the politically relevant sections. 
roads and lace the air with telegraph wires; we add knowledge to knowledge, and utilize invention after invention; we build schools and endow colleges; yet it becomes no easier for the masses of our people to make a living. On the contrary, it becomes harder. The wealthy class is becoming more wealthy; but the poor class is becoming more dependent. The gulf between the employed and the unemployed is growing wider; social contrasts are becoming sharper; as liveried carriages appear, so are barefooted children.

These words were written in 1879 by Henry George ([1879] 1926, pp. 390-91), the prophet of American reform, and are excerpted from his book Progress and Poverty. Serialized in the United States, translated into the major European languages, and selling some two million copies in the next two decades, this book left an indelible impression on the generation of progressive thinkers in America. In retrospect, the enthusiastic response the book elicited from clergy, businessmen, academics, professionals, and philanthropists seems all the more startling in view of the author's expressed commitment to socialism: "The ideal of socialism is grand and noble; and it is, I am convinced, possible of realization" (George 1926, p. 319). That was written at a time when the spirit of laissez-faire reigned supreme and the principle of "the survival of the fittest" enjoyed the status of unassailable truth. The book's phenomenal success is testimony to the sweeping change in popular mood that the country underwent within two decades and that marked the transition to the Age of Reform in American politics (Aaron 1951, p. 67; Hofstadter 1955; Goldman 1956, p. 76; Resek 1967, p. xxi).

The best indicator of the new mood in the land was the change in mainstream Protestantism. Toward the end of the 19th century, the predominantly individualistic Evangelicalism of the pre-Civil War era noticeably yielded to socially conscious and reform-oriented forms of Christianity. Throughout the country, evangelical establishments, such as Mead's alma mater, Oberlin College, were spreading the word that shaping man in the image of God meant not only purifying his soul through the gospel of Jesus but also changing the environment that corrupted his spirit and bred social ills. Henry King's Theology and the Social Consciousness and John Commons's Social Reform and the Church are just two examples of the voluminous literature of the $1890 \mathrm{~s}$ that spurred municipal reforms, the survey of immigrants, and the formation of settlements, and that helped to shape the idea of Christian social work as a practical way of improving society (Smith 1957; Barnard 1969). The Christian socialism of this period was but a radical expression of the Social Gospel movement that challenged the Christian establishment in the last decade of the 19 th century. Indeed, when the Rev. W. D. P. Bliss ([1890] 1970, p. 352-53) demanded "the ownership, or at least, the con- 
trol of, city railways; the immediate cessation of giving away or selling valuable street franchises to private monopolists" and insisted that "Christian socialists should teach by fact and not by sentiment; by fact about city gas works, not by mere talk about city brotherhood," he simply was following to the end the logic of new Evangelicalism.

The reformers of the Progressive Era owed much of their inspiration to the critical ferment stirred by the Social Gospel. Their arguments against old-school liberals, for whom government interference in the free-market economy was a crime against nature, bore a particularly strong resemblance to the rhetoric of Christian socialists. Along with the latter, the progressives cast aside still-potent social Darwinism and embraced George's argument that, unless ways were found to check the relentless drive toward monopoly and the growing polarization of wealth and poverty, America would soon find itself in the same sorry state as the injustice-ridden regimes of the Old World. The most important progressive reforms - the establishment of the Interstate Commerce Commission, the Conservation Act, the Federal Reserve Act, the food and drug law, the federal workmen's compensation program, the Adamson Act mandating an eight-hour working day on interstate railroads, the electoral reforms, including the initiative, the referendum, the direct election of U.S. senators, and women's suffrage-demonstrate the extent of the break with the old liberalism that occurred in the Progressive Era. To be sure, the reforms in question fell short of the social legislation adopted around the same time in Europe, notably in England (Orloff and Skocpol 1984), but they were precipitous enough to provoke the charges-from both the political Right and Left-that Progressivism is the first step toward socialism.

If the critics on the Right saw progressive reforms as a dangerous interference with natural market forces, for the critics on the Left these were but half measures. For the very success of progressive reform, socialists charged, furnished proof that state control does work, that equalizing opportunity is indeed the government's business. That is what the socialist critics of laissez-faire capitalism had been saying all along. The progressive reforms, according to them, were palliatives designed to stem the irreversible movement toward a social and industrial democracy, half-hearted attempts to refurbish the capitalist system that needed to be revamped on a fundamentally new - socialist - basis. The appeal of this argument was considerably enhanced by moderation within the socialist movement. Emboldened by their electoral successes and the growing interest from respectable middle-class audiences, socialists all over the world were eager to assure the public that they had "no intention of appealing to force," that the time had come "to free Socialism from the Marxian system," which in the long run turned out to be "more of a 
hindrance than a help" (Sombart [1909] 1968, pp. 225, 90). "I am opposed to any tactics which involve stealth, secrecy, intrigue, and necessitate acts of industrial violence for their execution," declared Eugene Debbs (1912, p. 483), the pragmatic leader of the Socialist party of America. No wonder that by 1912 he could claim the support of five daily papers, 250 weeklies, 50 mayors, and one congressman and was polling close to a million votes in the presidential election-not sufficient for the party to become a mainstream one but enough to make opponents worry (Pease 1962, p. 216; Fried 1970, pp. 377-90).

There is a long-standing debate about the causes of the failure of socialism in America. According to one school of thought, socialism never had a chance in this country because it is incompatible with the individualistic American creed. Others argue that socialism did strike roots in America and that its effect on the political scene here is vastly underestimated (for an overview of this debate, see Laslett and Lipset 1974). There is also a third opinion, expressed most cogently by Albert Fried: "Socialism was not an alien but an integral part of the American past. Here, in fact, lay the root of its 'failure,' of its inability to develop into an independent sturdy movement. In Europe, Socialism, with its radically egalitarian ethic, stood in militant opposition to, or at war with, established authority. . . . But the ideals of American Socialism were embodied, implicitly at least, in the creation of America itself" (1970, p. 2). Although this statement cannot be accepted without serious qualifications, it does contain a kernel of truth, and it certainly helps us understand the progressive thinkers' well-known ambivalence toward socialism (Goldman 1956, p. vii; McNaught 1974, p. 415). Indeed, Woodrow Wilson was not simply using scare tactics when he reminded his audience during his first presidential campaign, "I need not tell you how many men were flocking over to the standard of the Socialists, saying neither party any longer bears aloft an ancient torch of liberty" ([1912] 1962, p. 375). Nor did Theodore Roosevelt exaggerate much when he said, "I am well aware that every upholder of privilege, every hired agent or beneficiary of the special interests, including many well-meaning parlor reformers, will denounce this [Progressive platform] as 'Socialism'" ([1912] 1962, p. 318).

Herbert Croly, the first editor of The New Republic and a staunch supporter of the Bull Moose party, was even bolder in his recognition of the affinity between the socialist and progressivist programs: "The majority of good Americans will doubtless consider that the reconstructive policy, already indicated, is flagrantly socialistic both in its method and its objects; and if any critic likes to fasten the stigma of socialism upon the foregoing conception of democracy, I am not concerned with dodging the odium of the term" (1909, p. 209). One can also detect the unmistakable imprint of socialist ideas in Jane Addams's resolute denunciation of "the 
overaccumulation at one end of society and the destitution at the other" and in her keen awareness of the paradox of a "large and highly developed factory [that] presents a sharp contrast between its socialized form and its individualistic aim" (1910, p. $126 ; 1902$, p. 139). Socialism was very much on the minds of the progressives. The latter often sounded defensive in front of their socialist opponents (e.g., Roosevelt 1909), but they also shared with them humanitarian objectives. Progressive reforms reflected their desire to socialize American democracy, their "passion for the equalization of human joys and opportunities" (Addams 1910, p. 184). Much as they wished for the socialism of opportunity, however, progressives were leery of the socialism of property, endorsing it chiefly in such areas as municipal services and public transportation. The massive nationalization advocated by orthodox socialists, according to progressives, was a false solution, for it would only dampen the entrepreneurial spirit so essential to American life, undermine its basic freedoms, and eventually stifle the opportunity it aimed to promote. The solution to the problem was reform not revolution, a program of reconstruction that would build on the strengths of the American democratic tradition yet would not hesitate to dispense with the old institutions that stood in the way of socializing opportunity.

To sum up, the progressive agenda was shaped in the course of the polemics with the proponents of unrestrained capitalism and with the adherents of socialist teaching. It also reflected the considerable influence of social Christianity. Progressivism represented an attempt to come to grips with "some of the more glaring failures of capitalism" (White 1957, p. 46). It was "plainly influenced by socialism" (Goldman 1956, p. vii), which served the progressives as both a negative and positive frame of reference. In substance, Progressivism represented "a dual agenda of economic remedies designed to minimize the dangers from the extreme left and right" (Hofstadter 1955, p. 236). This dual agenda called for a new outlook, a philosophy of a different kind. It was to be both conservative and radical, pragmatic and principled, faithful to the nation's democratic heritage yet critical of its political and economic practices. This dual agenda of American Progressivism found expression in the life and work of George Herbert Mead.

\section{THE MAKING OF A REFORMER: MEAD'S PATH FROM EVANGELICALISM TO PROGRESSIVISM}

Few American reformers on the path to Progressivism escaped the influence of liberal Christian theology, and Mead in this respect was no exception. His father, Hiram Mead, a minister in the Congregational church and a prominent educator, taught homiletics at Oberlin Theolog- 
ical Seminary. Mead's mother, Elizabeth Storrs Billings, was a strongwilled, dignified, very religious woman; for a number of years, she served as president of Mount Holyoke College and later taught at Oberlin College. With a background like this it was logical to expect that Mead-a rather shy, serious, well-behaved boy-would take up the ministry. Oberlin College, where Mead matriculated in 1879, was a perfect place to start such a career. Founded by clergy and renowned for its piety and abolitionist sentiments, Oberlin was a stronghold of the spirit of old New England Puritanism, which for decades filled its students with "a zeal for bettering the life of mankind as the highest expression of religious duty" (Barnard 1969, p. 126). Yet just around the time when Mead was ready to enter college, the winds of change began to blow through American institutions of higher learning. Darwin's theory of evolution, reinforced by German historical criticism of the Bible, was winning numerous converts among the public, making a revision of Christian dogma a necessity. The Social Gospel movement burst onto the scene, propelled by its proponents' ardent belief in the power of Christian social work to cure society's ills. About this time, various reform schemes started attracting followers among students and faculty in colleges and universities all over the country. Oberlin College was at the center of the new currents of theological, political, and social thought. In the 1880 s and 1890 s, it was the site of several conferences in which the Rev. Washington Gladden, Walter Rauschenbusch, Lyman Abbot, Richard T. Ely, Carroll D. Wright, and scores of other liberal theologians and reformers debated topics ranging from Darwinism and Scripture, to intemperance and crime, to immigration and poverty. In later years, an array of progressive and socialist thinkers were invited to speak directly to student audiences, including such luminaries as Robert M. La Follette, Jane Addams, Lincoln Steffens, Jack London, and John Spargo. Among the people most talked about at Oberlin during this period was Henry George. In 1887, he visited the campus and spoke on the issues of reform to an enthusiastic audience of faculty and students (Barnard 1969, p. 62).

Mead's early correspondence amply documents the depth of his religious feelings, the earnest commitment to spreading the word of God inculcated in him during the college years. "I believe Christianity is the only power capable of grappling with evil as it exists now," wrote Mead to his college friend Henry Castle (MP April 23 and March 16, 1884, b1, f1); "There can be no doubt of the efficacy of Christ as a remedial agent

${ }^{3}$ The letters "MP" stand here and elsewhere in the text for the George H. Mead papers, a collection of letters and manuscripts by Mead in the Special Collections Department of the Joseph Regenstein Library, University of Chicago. The letters " $b$ " and " $f$ " followed by a number indicate, respectively, box number and folder number 
and so I can speak of him as such. ... The moral realities of the world are powerful enough to stimulate me and Christianity lays the strongest hold upon me." There were also some indications that Mead was affected by the critical currents of the day. These indications are not to be found in the four signed articles that Mead $(1881,1882 a, 1882 b, 1882 c)$ published in the Oberlin Review and that deal with conventional literary and philosophical subjects, but rather in the unsigned editorials that he and his coeditor, Henry Castle, wrote during their last year in college and that point to the influence of liberal theology on Mead's thinking. ${ }^{4}$ Noting with satisfaction that "the religious craze against evolutionary theories is dying out," the editors urged a rapprochement between church dogma and the theory of evolution (Editorial 1882). A long editorial (1883) drew attention to the growing number of students passing up the ministry as a vocation because of their doubts about the veracity of church doctrine and insisted that "this doubt is, as an almost universal rule, honest doubt." At Oberlin, Mead also acquired his political allegiance. As his letter to the editor of The Nation (Mead 1884) suggests, his political views in the college years followed middle-class Republicanism, which was then prevalent at Oberlin and which Mead was ready to defend against the attacks of its critics. Despite his later ambivalence about Roosevelt and admiration for Wilson, Mead would remain loyal to the Republican party throughout his life.

After college, Mead confronted a difficult career choice. Two possibilities appealed to him-Christian social work and teaching philosophy. What he liked most about the former was the chance to work for people and somehow to make the world a better place. The latter career attracted Mead because of the secure academic environment and an opportunity to continue his philosophical speculations, which he had grown increasingly fond of in his last year of college. There were problems with both lines of work. A career in Christianity required belief in God, which over the years Mead found difficult to sustain. To follow this path, wrote Mead in a letter to Henry Castle (MP March 16, 1884, b1, f1), "I shall

where a particular document is located. Mead's letters to Castle are gathered in box 1, folders 1-4. Editorial changes in the following excerpts from Mead's letters and manuscripts are limited to typographical errors and punctuation. Two of the letters pertaining to Mead's interests in socialism and reform have been transcribed by the author and are published in the Fall 1987 issue of Symbolic Interaction (see Shalin 1987).

${ }^{4}$ In his senior year, Mead was elected an editor of the Oberlin Review and charged with the responsibility of assisting Henry Castle, his close friend and fellow editor, in the editorial department. Most of the editorials published during the academic year of 1882-83 were probably written by Castle, but some, judged by their style and other telltale signs, were penned by Mead, and virtually all must have had at least his tacit approval. 
have to let persons understand that I have some belief in Christianity and my praying be interpreted as a belief in God, whereas I have no doubt that now the most reasonable system of the universe can be formed to myself without a God. But notwithstanding all this I cannot go out with the world and not work for men. The spirit of a minister is strong with me and I come fairly by it." The alternative career had problems of its own. "There is a great deal of good work that needs to be done in popularizing metaphysics among common people," wrote Mead in the same letter, but this option did not appear to satisfy his passion for commitment: "I want to give myself to that which I can give my whole self to. . . ." For several years, Mead remained troubled by this choice. Again and again, he would weigh the arguments, assess his chances, extol the virtues of the Christian faith, and then confess his inability to follow suit. "I need the strength of religion in my work," confided Mead to his friend (MP February $23,1884, \mathrm{b1}, \mathrm{f1})$; "Nothing could meet the wants of mankind as Christianity, and why not have a little deception if need be? . . . And yet as I look at it now, there is hardly any position I would not rather occupy than that of a dogmatic theologian. I would rather be a school teacher than a Joseph Cook dabbling in metaphysics."

No one knows how long this torturous quest would have continued had it not been for Henry Castle,${ }^{5}$ who finally convinced Mead to join him in Cambridge, Massachusetts, where he had settled earlier to study law. Once his mind was made up, Mead threw himself into the study of philosophy. Of all possible specializations available to him when he enrolled in the Department of Philosophy at Harvard, he selected the one most peripheral to the discipline's traditional concerns-physiological psychology. The reason for this choice, according to Castle ([1889] 1902, p. 579), was Mead's belief that he had found "a harmless territory in which he [could] work quietly without drawing down upon himself the anathema and excommunication of all-potent Evangelicism." The spirit of a minister, however, was too strong in Mead, and it was not long before the need to serve people reasserted itself in him.

In the fall of 1888 , after successfully completing a year at Harvard,

\footnotetext{
${ }^{5}$ Mead's difficulties of those years were financial as much as intellectual. After college, Mead had to support himself and possibly his mother first by working as a schoolteacher and then as a member of a survey team of the Wisconsin Central Railroad Company. It does appear that Henry Castle, the son of wealthy American missionaries in Hawaii, furnished Mead with some financial assistance during the latter's studies at Harvard and later in Germany. In 1891, Mead married Castle's sister, Helen, and eventually inherited, through her, part of the Castle family fortune. The influence of Henry Castle on Mead's personal and intellectual growth was great indeed, and one can only hope that the story of this beautiful friendship, which ended in 1895 with Castle's tragic death, will one day be told.
} 
Mead won a scholarship and went to Germany, ostensibly to continue his studies toward a doctoral degree. Yet his mind would soon turn to politics, stimulated by the burgeoning reform movement in Germany. The extent of government involvement in the issues of social security, the popularity of the Social Democratic party, and particularly the respect socialism commanded in academic circles deeply impressed Mead, who found the situation in Germany to be in sharp contrast to the one back home, where the idea of state involvement in labor-management relations was still suspect and the term "socialism" had a somewhat odious connotation. A few months after settling in Germany, Mead experienced something akin to conversion. His letters of this period are brimming with enthusiasm for social reforms and the prospect of transplanting them to the States. He talks about "opening toward everything that is uplifting and satisfying in socialism" (MP August 1890, b1, f3), urges Henry "to get a hold upon the socialistic literature-and the position of socialism here in Europe" (MP October 21, 1890, b1, f3), and deplores in the most sweeping terms American politics: "American political life is horribly idealess. ... Our government in ideas and methods belongs so to the past. ... We had never had a national legislature in which corrupt motives in the most pecuniary form could be more shamelessly used than in the present" (MP October 21 and 19, 1890, b1, f3). ${ }^{6}$

Somewhere along the way doubts about his career choice came to haunt Mead again. Invoking his abiding need for commitment, he declared a readiness to go into politics, at least on a trial basis: "Life looks like such an insignificant affair that two or three or more years of utterly unsuccessful work would not seem to me in the slightest dampening, and the subjective satisfaction of actually doing what my nature asked for of infinitely more importance than anything else. . . . I mean that I am willing to go into a reform movement which to my eyes may be a failure after all; simply for the sake of the work" (MP October 19, 1890, b1, f3). Soon a plan was formed in Mead's head, in which he envisioned himself and his friend, Henry Castle, after a thorough study of the German scene, coming back to the States, securing control of a newspaper, and launching a crusade for social reform:

The immediate necessity is that we should have a clear conception of what forms socialism is taking in [the] life of European lands, especially of the

\footnotetext{
${ }^{6}$ Mead's criticism of this period, and particularly his lamentations about the lack of a "national feeling" in America (MP October 19, 1890, b1, f1), bears a startling resemblance to the criticism of the American scene developed by the members of the Nationalist Club-a reform organization established by the followers of Bellamy, the author of the popular utopia, Looking Backward, which advocated the cause of socialism in the United States.
} 
organisms of municipal life-how cities sweep their streets, manage their gas works and street cars, their Turnvereins, their homes of prostitution, their poor, their minor criminals, their police, etc., etc., that one may come with ideas to the American work. Now Henry you must come and at least get such a share in these subjects and hold of the social political literature that you can go right on when we are back. I must teach at first for I must earn money, but I shan't keep it long. I want more active life. . . My vague plan now is that I go to the university of Minnesota as a teacher-and you to Minneapolis as lawyer and that we finally get control of the Minneapolis Tribune. This is of course hazy but Minneapolis has very large attractions for this work-it is young, not sunk into the meshes of any traditional machine, and yet beyond the boom period. But this is entirely superfluous castle building but to go to some city we must and to go to work and fail if need be, but work in any case and work satisfactorily. [MP August 1890, b1, f3]

What is particularly impressive in Mead's thinking of those years is his clear understanding that the city is bound to play a special role in future reforms. City Hall, insisted Mead in a manner reminiscent of Christian socialists, is the true locus of the reform movement, and city politics is the place where the reconstruction of America should start: "We must get into politics of course-city politics above all things, because there we can begin to work at once in whatever city we settle, because city politics need men more than any other branch, and chiefly because, according to my opinion, the immediate application of principles of corporate life-of socialism in America must start from the city. . . . If we can purify there, we can throughout, if we could not there, we could not anywhere. If we can give American institutions the new blood of the social ideal, it can come in only at this unit of our political life and from this starting point it will naturally spread" (MP October 21 and 19, 1890, b1, f3).

Unlike Mead, Castle was a man of more practical bent. He shared many of Mead's ideals and was strongly affected by the reform currents in Germany, where he traveled extensively, ${ }^{7}$ yet he thought Mead's plans of going into politics and reforming America via city hall somewhat utopian and did not hesitate to impress this on Mead. Without Castle's financial backing and his editorial skills, Mead had to put his plans on the back burner. Meanwhile, his life took a decidedly new turn. In 1891, Mead was appointed an instructor at the University of Michigan, where he met his future colleague and friend, John Dewey. An academic of no small

7 "The importance of social democracy here is tremendous, but not in the least alarming," wrote Castle ([1894] 1902, p. 784) to his parents while on a trip to Germany. "It simply stands as a protest against the existing conditions, not merely on their economical but also on their political side. The leaders are men of brains and education, whose influence is on the side of the general democratic movement after all, and as such useful and necessary." 
renown even in those days, Dewey shared Mead's passion for social democracy and philosophical disquisition. As early as 1888, Dewey ([1888] 1969 , p. 246) speculated about the "tendency of democracy toward socialism, if not communism" and claimed that "there is no need to beat about the bush in saying that democracy is not in reality what it is in name until it is industrial, as well as civil and political ... a democracy of wealth is a necessity." The two pursuits that Mead was trying to reconcile were united in the life of this remarkable man. Indeed, Dewey was the foremost example of an American academic successfully combining research and political engagement, and, as such, he was bound to become a role model for Mead.

Not much is known about Mead's stay at Ann Arbor. He still seems to have harbored some hopes for direct political engagement, as indicated, for instance, by his enthusiastic response to the idea of a socialist weekly, which Dewey, Mead, and Park were contemplating for a while (MP February 28, 1892, b1, f3; see also Raushenbush 1979, pp. 18-21; Joas 1985, p. 21). What is clear is that Dewey and Mead formed a friendship that each of them would later claim was his most precious possession. When Dewey was offered the chairmanship at the University of Chicago, he made his acceptance contingent on the appointment of Mead (who never completed his doctoral thesis) as an assistant professor in his department. It was at the University of Chicago that Mead's career as a reformer began to flourish. In the years following his move to Chicago, Mead joined the City Club, an organization of reform-minded professionals and businessmen, of which he became president in 1918. Mead worked in close association with such people as Graham Taylor and Jane Addams, and for more than a decade he served as treasurer of the University of Chicago settlement. ${ }^{8}$ Along with Dewey, Mead was keenly interested in reform of the Chicago school system and at some point headed the Chicago Educational Association and the Vocational Guidance League. He was vice-president of the Immigrants Protective League of Chicago. On several occasions, he served as a member of the strike settlement committees. By 1910, Mead was generally recognized as one of the leaders of the Progressive movement in the city of Chicago.

The first expressly political publications of Mead-a review of Le Bon's Psychology of Socialism and an article "The Working Hypothesis

\footnotetext{
${ }^{8}$ Graham Taylor, a social worker with long experience in the Chicago reform movement, wrote to Mead's son on the death of his father, "More than he or any of us know the social settlement and city club movements owed much to his enlistment and guidance" (MP Taylor to Henry Mead, September 26, 1931, b1a, f7).
} 
in Social Reform"-testify to Mead's continued preoccupation with socialism. In his words, "Socialism, in one form or another, lies back of the thought directing and inspiring reform" (Mead 1899a, p. 367). But one can also detect a new critical note in Mead's treatment of socialism, or rather a "doctrinaire" and "utopian" version of it, to which Mead juxtaposes the "pragmatic" and "opportunist" approach of progressive reformers. Indicative in this respect is Mead's review of Le Bon's book. He agrees with the author that socialist teaching has a tendency to become dogmatic insofar as it lays claim to a priori validity. He also renounces all versions of socialism that sanction violent means, and he expresses skepticism about Marx's economic analysis, which he finds at odds with modern economic and political realities. Nevertheless, he resolutely parts company with Le Bon and other critics of socialism who confuse its doctrinaire form with its humanistic content. The programmatic and apocalyptic aspects of socialist teaching may be obsolete, Mead argues, but its quest for justice is not; this quest is now taken over by social democrats who have denounced revolutionary violence and turned into reformers: "The socialists are becoming opportunists. They are losing confidence in any delineation of the future conditions of society-any 'vision given on the mount.' . . . Socialistic thinking may be different in France and England, but it is the same great force and cannot be studied in the camp of the programmist alone. It is coming to represent, not a theory, but standpoint and attitude. . . . We have, in general, given up being programmists and become opportunists. We do not build any more Utopias, but we do control our immediate conduct by the assurance that we have the proper point of attack, and that we are losing nothing in the process. We are getting a stronger grip on the method of social reform every year, and are becoming proportionately careless about our ability to predict the detailed result" (Mead 1899b, pp. 405-6, 409).

Mead's political beliefs at this point, and specifically his emphasis on pragmatism and opportunism, are reminiscent of Eduard Bernstein's brand of social democracy, with its motto, "The movement is everything, the goal is nothing." That is to say, Mead is cognizant of socialism's historical import and sympathetic to its humanitarian objectives: "Socialism presented at least for some decades the goal that society must contemplate, whether it will or not [be] a democratic society in which the means of social expressions and satisfactions are placed at the disposal of the members of the whole community" (MP b2 addenda, f27). Nonetheless, Mead grows increasingly skeptical about socialist means. He continues to stress socialism's historical importance but mostly in the past tense, viewing it as a movement that shook the world from its dogmatic slumber but that had now outlived its usefulness, at least in the United States. By the 
early 1900 s, Mead fully identified himself with the Progressive creed, to which he remained faithful the rest of his life. ${ }^{9}$

It would not be appropriate to speak about Mead's movement away from socialism, for there is not enough evidence to assert that he ever was a card-carrying Socialist to begin with. The question that one may pose is, Why did Mead not embrace more openly socialist premises? Part of the answer to this query, I believe, can be gleaned from the status of politically engaged scholarship in this period. The marriage of scholarship and advocacy in American academia at the time was far from peaceful and harmonious (Furner 1975). The professor's right to speak on controversial issues was acknowledged, albeit within clear limits. An outright endorsement of socialism was pretty much out of the question. ${ }^{10}$ Instructors willing to take a political stance had to make sure that their views bore the imprimatur of science and dovetailed with the American democratic creed. Bemis, Ross, and some other instructors who lost their jobs in the late 19th century because of their political engagements did, in one way or another, overstep the boundaries of what most in academia then thought were the standards of objectivity and disinterestedness. Others, such as Richard T. Ely, Charles Zueblin, and Thorstein Veblen, had to go through endless explanations and humiliating denials concerning their alleged prosocialist sentiments. ${ }^{11}$ Still, quite a few academics with various degrees of commitment to the ideals of social democracy, such as Seligman, Commons, Bird, and Dewey, found a formula that seemingly reconciled scholarship and advocacy. The common denominator that united these otherwise disparate characters was an unswerving commitment to reform, combined with a vigorous renunciation of violence as the means

\footnotetext{
${ }^{9}$ In a letter to his daughter-in-law, Mead, (MP March 10, 1919, b1, f16) refers to his duty as president of the City Club to nominate a few of its members as candidates for its leading positions: "Now I will spend hours on the phone securing the consent of five-well balanced between the radicals and conservatives-which means two reds, two blues and one Menshevik." Somehow, one gets the impression that Mead's sympathies were, at this time, with the Mensheviks, i.e., with the moderate social democrats committed to democracy, reform, and the rule of law.

${ }^{10}$ Even in the heyday of Progressivism, teaching socialism in colleges was seen as a disloyal act. Here is a statement on the subject adopted in 1914 by the state of Wisconsin Republican Convention: "We favor the principle of Lehrfreiheit. The truth must and shall be taught. However, Socialism is not a demonstrated truth and we regard it as destructive of every principle of government that is dear to the American people and the mind of the student should be kept free from its misleading theories" (quoted in Mead 1915, p. 351).

${ }^{11}$ One of Mead's letters to his wife contains an interesting reference to Veblen: "Had a pleasant call upon Veblen, who is pained because the Socialist Review says his doctrine is good socialism" (MP May 13, 1901, b1, f5). Veblen was no socialist, to be sure, but his precarious position at the University of Chicago must have made him sensitive to such suggestions.
} 
of social reconstruction. That, of course, was the basic creed of Progressivism, which had just started coming into its own. It is this rising current in American politics that provided legitimation for the incipient fusion of scholarship and advocacy and that helped to secure a niche for all those who sought to partake in the reform of American society without jeopardizing their academic positions. Mead's political views, or at any rate his public stance, showed that he understood the limits of the possible for an academic in the Progressive Era.

Still, we need to bear in mind that Mead's high regard for socialism remained unchanged throughout his life. He greeted with enthusiasm the democratic February Revolution in Russia (Mead 1917d), and he supported the program of the British Labour party (Mead 1918). "What has been said [about socialism]," wrote Mead in a characteristic passage, "has been said with a profound realization of the past and future import of its economic gospel, even if it has been a gospel only according to Marx" (MP b3 addenda, f7). Mead's highest praise, however, was reserved not for socialists but for people like Jane Addams and R. F. Hoxie, radical democrats thoroughly committed to the struggle for the rights of the underprivileged (Mead 1907, 1916-17). What attracted Mead to these people was that, without wrapping themselves in the revolutionary flag, they were searching for ways of realizing the revolutionary ideals that inspired socialist critics of society. This quest for peaceful revolution provides a key to Mead's own theory of the reform process.

To sum up, Mead's intellectual and political growth was marked from the beginning by the tension between his evangelical desire to serve people and his predilection for an academic career. This tension was resolved when the emerging movement for social reform legitimized the fusion of scholarship and advocacy in the academic setting. Along with some other social scientists of his day, Mead was influenced by socialism, or rather a social democratic version of it that renounced all forms of revolutionary violence and endorsed strictly democratic and political means of effecting social change. After establishing himself in academia, Mead embraced the Progressivist creed, yet even then he did not cease to see the historical importance of socialism or to acknowledge his debt to it. By the end of the 19 th century, Mead emerged as a "radically democratic intellectual" (Joas 1985 , p. 10), a reformer deeply involved in progressive causes, and a budding academic searching for a theoretical rationale for a far-reaching yet peaceful reconstruction of American society.

\section{INSTITUTIONALIZING REVOLUTION: MEAD'S THEORY OF THE REFORM PROCESS}

Progressive reformers differed among themselves on the etiology of current problems, the ultimate objectives of reform, and the best strategies 
for social reconstruction, but they all agreed that the gap between democratic ideals and American reality had grown intolerably wide. The founding fathers envisioned the United States as a community of civilminded and well-informed citizens consciously shaping their destiny under the protection of constitutionally guaranteed freedoms. The reality, with its predominance of poorly educated workers and illiterate immigrants, made a mockery of this Jeffersonian ideal of popular democracy. Like all progressives, Mead was very much aware of "the chasm that separates the theory and practice of our democracy," yet he went farther than most in delineating "the tragedy of industrial society" with its "routine and drudgery of countless uninterested hands" and "the blind production of goods, cut off from all the interpretation and inspiration of their common enjoyment" ([1923] 1964, p. 263, [1925-26] 1964, pp. 29596). The plight of workers caught in the meshes of the modern factory system attracted his special attention.

The Industrial Revolution, according to Mead, makes the worker's participation in the democratic process problematic, because it minimizes his educational needs, cheapens his labor, and dehumanizes his life. The modern worker is in some sense worse than his medieval counterpart, whose skills, slowly acquired and hard to replace, "made of him an admirable member of the older community. . . . It is the machine that has taken possession of the trades, has displaced the artisan, and has substituted for the artisan, who makes an entire article, a group of laborers who tend the machine. The effect of this upon the training of the laborer has been most deplorable. The more the machine accomplishes the less the workman is called upon to use his brain, the less skill he is called upon to acquire. . . . The man who tends one of these machines becomes a part of the machine, and when the machine is thrown away the man is thrown away, for he has fitted himself into the machine until he has become nothing but a cog" $(1908-9 a$, pp. $370-71 ; 1908$, p. 20). The machine is a product of the social forces over which no individual has control, yet its devastating effects have been multiplied by the callous attitude of its owners: "Thus the machine is a social product for which no individual can claim complete responsibility. Its economic efficiency is as dependent on the presence of the laborer and the market for its products as mechanical structure is dependent upon the inventor, and its exploitation upon the capitalist. But the group morality under which the community suffers, recognizes no responsibility of the exploiter to the laborer, but leaves him free to exhaust and even maim the operator, as if the community had placed a sword in his hand with which to subjugate" (1907, p. 127).

The situation is further exacerbated by the current educational system, which perpetuates the division between the two kinds of skills-one for laborers and the other for higher orders of society. An investment into the 
future worker's education beyond what is necessary to fulfill his role as a laborer is considered a luxury, and so he rarely moves beyond elementary school and is often compelled to start work even earlier. The wealth of cultural goods that belongs to everyone in the community remains closed to him: "Cultured classes in some sense have an access to this wealth, which is denied to masses in the community. . . . We are encouraging a class distinction which must be destructive of American democracy if it persists . .." ([1930] 1964, p. 403; 1908-9b, p. 157). Bad as the position of the American-born worker is, it is worse for the immigrant. He is brought to the United States as a source of cheap labor and, lacking English and education, becomes easy prey for employers. The latter, Mead concluded from his many encounters with Chicago businessmen, "had absolutely no feeling of responsibility to the immigrant, or the sense of debt which Chicago owes to the immigrant. . . He [the immigrant] comes ignorant and helpless before the system of exploitation which enwraps him before he leaves the old country and may last for two generations after he enters our gates. Our government has nothing to offer him by way of protection but the doctrine of the abstract human rights of man, a vote he cannot intelligently exercise, and the police to hold him in his place" (1909, pp. $222-23 ; 1907$, p. 123). Whatever American democracy has to offer the well-to-do, Mead concludes, falls far short of its promise when it comes to the millions of working-class people effectively excluded from meaningful participation in the life of the community. If modern America is to fulfill the democratic aspirations of its founding fathers, it has to "eliminate the evils to which economic inferiority exposes great masses of man," it has to provide equal access to cultural goods for all members of the community, and it must imbue the laborer's work with meaning: "In the bill of rights which a modern man may draw up and present to the society which has produced and controls him, should appear the right to work both with intelligent comprehension of what he does, and with interest. For the latter one must see the product as a whole . . " (1908-9a, pp. 381, 378).

Many of the above themes, as one can readily see, run parallel to the familiar socialist critique of capitalist society. The likeness is particularly striking if we think about the young Marx's philippics against the effects of the division of labor on the working man. Indeed, both Marx and Mead deplored the dehumanizing consequences of the factory system, both sought to restore the producer's sense of the product as a whole, and both resisted a wholesale renunciation of modernity and invested much hope in the future of science and technology. Beyond these parallels, however, one finds differences that set Marx's socialism sharply apart from Mead's progressivism. For Marx, the real culprit is capitalism, with its private ownership of the means of production, inherently unstable economy, and that perennial scourge-alienated labor. Capitalism must 
be abolished, if necessary by revolutionary force, and, if the dictatorship of the proletariat means curtailing individual freedoms, that is no great loss, since the civil liberties guaranteed by bourgeois society are a sham anyhow. When the considerations of justice and equality collide with those of freedom and democracy, the former are to be given higher priority in Marx's system. Not so in Mead's book. Democracy gets the top billing there. To be sure, justice is important for Mead, as it is for any progressive-it is a vital condition of genuine democracy-yet, if pursued for its own sake, radical equality is bound to impinge on civil liberties and undermine democratic institutions. Justice must be pursued as far, and only as far, as necessary for securing for every member of society an opportunity to participate in the democratic process. This last point needs further elaboration.

Underlying the Progressive movement was the realization that economically unregulated and socially unconstrained democracy flourishing under laissez-faire capitalism creates an underclass that is, de jure, free yet, de facto, excluded from meaningful participation in the democratic process. The United States, a country that prided itself on its commitment to democracy, was willing to tolerate utterly degrading human conditions, including the most shameful exploitation of woman and child labor. In the name of freedom of contract, freedom of trade, and so on, employers were able to impose on workers the terms of contract they wished to, even when this meant paying starvation wages. Clearly, progressives concluded, civil rights alone could not guarantee personal dignity and ensure the realization of human potential to which every member of society is entitled. A measure of economic well-being and educational opportunity is imperative for a democratic society. This is what Mead had in mind when he declared that "abstract human rights" offer little protection to immigrant workers, and what Dewey meant when he said that "actual and concrete liberty of opportunity and action is dependent upon equalization of the political and economic conditions under which individuals are alone free in fact, not in some metaphysical way" (1946, p. 116). This progressive stance had far-reaching implications. It implied that "poverty is a result of a faulty organization of society, and the organization of society can be changed" (MP b2 addenda, f26). It led to the conclusion that "community has a right to exert control over corporation" (MP b7, f8). And, by bringing to light "singular evils which have resulted from corporate property" (MP b7, f8), it hastened the end of laissez-faire capitalism in the United States.

As one could imagine, this attack on 19th-century capitalism met stiff resistance from die-hard defenders of the old ways, who decried the progressive program as an unconstitutional abridgment of democratic liberties. Yet most progressives stood firm and did not waver in their 
conviction that society's interference in the market process is both justifiable and necessary, that is, insofar as this interference makes democracy more equitable and to the extent that it leaves the core of civil liberties intact. The last point is particularly important, for it underscores the fact that progressives had more faith in bourgeois democracy than Marxists did. They thought that civil liberties, constitutionally guaranteed and when necessary expanded, could provide a firm foundation for social reconstruction. Radical and revolutionary as this reconstruction might be, it had to be carried out by constitutional means, and its success had to be judged by the degree to which democratic values were preserved.

There is a phrase that crops up in Mead's writings-institutionalizing of revolution. Says Mead: "Revolutions might be carried out by methods which would be strictly constitutional and legal"; "Government by the will of the people means that orderly revolution is a part of the institution of government itself"; "When you set up a constitution and one of the articles in it is that the constitution may be changed, then you have, in a certain sense, incorporated the very process of revolution into the order of society" ([1915] 1964, pp. 150-51; MP b3 addenda, f29; 1936, p. 361). These statements, so emblematic of Mead's political thought, illuminate the widely held progressivist belief that radical change can be accomplished, without recourse to violence, by legitimate constitutional means. Revolution is not in itself a bad thing, according to Mead; it is "a summary reconstruction" that takes place when "a whole population is able to assume, for a time, the larger or more universal attitude" (MP Mead to Irene Tufts Mead, September 16, 1916, b1a, f13). As such, it represents a constructive force that must be harnessed by progressive legislation and directed by enlightened public opinion. This peaceful democratic revolution naturally presupposes that the democratic machinery is already in place, as, for instance, in the United States. The democratic alternative is very much in doubt where bourgeois democracy has not yet been established, which, Mead pointed out, was the case in most of Europe at the time. The appeal of socialism is strongest precisely in those countries where the struggle for bourgeois democracy is still going on: "Socialism abroad has been the outcome of popular struggle against governments which have been in the hands of privileged classes. . . . It has been democracy's fighting formation when opposed to a modern feudalism" $($ Mead $1917 d)$. Once democratic institutions are secured, socialism has done its job and must merge with other reform currents.

And what about capitalism? It certainly must be transformed but not necessarily into socialism. The future social order will be a radically democratic society that encourages personal initiative, equalizes opportunity in every sphere of life, and makes social reconstruction an ongoing 
concern. If capitalism is a thesis, then socialism is more in the nature of an antithesis-not a synthesis, as socialists would have it. If such a synthesis is possible at all, it is likely to be provided by progressivism. Here is how Mead laid out this idea in his course on the logic of the social sciences that he gave at the apex of the Progressive Era in the academic year 1911-12, as jotted down by one of his students: "Take case of Socialism vs. Individualism. Individualism owns capital, and Socialism asks that community shall own property-here [is] a clash. Solution involves say this form: individual initiative, individual control must be preserved and on the other hand public control must be preserved to protect the individual. How [can we] deal practically with this? Any number of schemes now appearing-interstate commerce, control of wages, control of conditions of labor, pensions, old age, out of work, sickness [benefits]. These statements are present solutions so that the clash is done away with" (MP b8, f8).

It would be a mistake to infer from this that Mead conceived the institutionalizing of revolution as a legalistic affair, some sort of neverending legislative process supervised by politicians and professional reformers. The legislative measures introduced by the progressive administrations were unquestionably valuable, and Mead was very enthusiastic about them (particularly about the platform of the Wilson administration), ${ }^{12}$ yet these legislative initiatives, he thought, were not in themselves sufficient to bring about a radical democracy, nor did they go to the heart of the reform movement. The ongoing reconstruction, as Mead envisioned it, was a multifaceted process designed to further the common interests of all groups and individual members of society and required the mobilization of public opinion, persistent attention of the press, cooperation of labor and business organizations, reorganization of the school, and direct participation of members of the scientific community.

It was an article of faith with Mead, and a starting point in his theory of the reform process, that underneath the conflicting interests of groups, classes, and nations lies a public good, waiting to be discovered and realized. "The real assumption of democracy inside the society of a nation and within the society of different nations," wrote Mead in an article from his little-known series of essays on democracy and war, "is that there is always to be discovered a common social interest in which can be found a solution of social strifes. . . . Democratic advance, therefore, has always been in the direction of breaking down the social barriers and vested

${ }^{12}$ In 1916, Mead wrote to his daughter-in-law, Irene Tufts Mead: "It is good that there is likely to be a popular majority for Wilson as well as the majority of the Electoral College, though I wish it had been larger, that is I wish that the country had swung further in the direction of progressivism . . ." (MP November 12, 1916, b1, f3). 
interests which have kept men from finding the common denominators of conflicting interests" (1917d; see also $1917 a, 1917 b, 1917 c, 1917 e)$. Mead did not specify what the public good is or how it is to be determined. Nor was he ready to identify it with majority vote. ${ }^{13}$ Yet he was convinced that some notion of public good must be a guiding force in the reform movement, and he vested the responsibility for its articulation in the general public. No government, elected body of representatives, or group of professional reformers in a democratic society could successfully complete its task without ordinary citizens, organized into voluntary associations. "The whole work of legislation," asserted Mead (1899a, p. 368), "is not only dependent upon public sentiment, at least in democratic countries, but it is finding constantly fuller expressions in other channels of publicity. ... . If only it becomes possible to focus public sentiment upon an issue in the delicate organism of the modern community, it is as effective as if the mandate came from legislative halls, and frequently more so." The public, as Mead, following Dewey, understood it, is a body of citizenry, well informed, conscious of its interests, and ready to take the problems of society as their own. This body is distinguished by its members' willingness to consider the interests of all groups and individuals from the standpoint of what is good for the community as a whole. The success of the reform process ultimately depends on how thoroughly the public is mobilized and how long it can sustain interest in the critical issues of the day.

A vital role in mobilizing public opinion belongs to the press, which has the power to focus attention on the ills of society and to keep them in the news until a consensus is reached regarding ways of dealing with the problem: "The newspaper, in its various forms of journal and magazine, is effecting changes that are assumed to be those which follow governmental action" (1899a, p. 368). So far, however, the overall performance of the press had been less than satisfactory. One serious problem, according to Mead, was that "our newspapers represent frequently, or generally, political parties, instead of bringing together the common interests of all of us-that they represent only single parts" (1912, p. 215). Another scourge, especially characteristic of the progressive press, was its pervasive "sensationalism [which] is the expression of a fundamental social conflict which the community feels but is not willing to come to terms with" (MP b4 addenda, f1). To fulfill its mission, the press would have to overcome its partisan bias and serve as a unifying force.

Mead had similar advice for the leaders of labor and business organiza-

${ }^{13}$ In one place, Mead refers to "a real democracy in which the theoretical political power is not simply in the hands of a voting majority, but in which the community life expresses the interests of all ..." (MP b2 addenda, f27). 
tions. He gave his full support to labor unions, whose combative spirit "is amply explained by the simple American demand for what one has confessedly earned, and the American determination to fight, if necessary, to get one's fair rights" (1907-8, p. 133). He urged business leaders to do their share in improving the conditions of labor and to get directly involved in the issues of minimum wage, working hours, workmen's compensation, and so on. Yet, he did not hesitate to chastise both labor and capital when he thought that intransigence on either side prevented a fair resolution of labor-management disputes (see MP Mead to Irene Tufts Mead, July 16 and 20, 1919, b1, f17; see also Diner 1980, pp. 148-51). The solution to labor strife that Mead personally favored was arbitration, to be conducted with expert mediators and under the eye of the public. The important thing was to keep searching for common ground, which, Mead was convinced, could always be found if only businessmen assumed their full responsibility as members of the community and workers aimed at "immediately possible achievements, with a vivid sense of the present reality of the means used and their necessary parity with the methods of the employers. Gradually the sense of community of interest between both arises, and with it growing interest in the actual struggle and a feeling of intense meaning that does not have to be projected into the future to get reality" (1899b, p. 411).

Schools have a vital part to play in humanizing American society. Progressive education, mandatory and free for all children, could at least partially offset "social restrictions which limit the development of children of poorer classes," and it could aid the progressive cause by bringing cultural goods to the poor and thereby "freeing . . . culture of its class connotation" (1964, pp. 405-6). Progressive education could also help to counteract the negative effects of the division of labor by furnishing the worker with knowledge of the industrial process as a whole. That, in turn, would require the elimination of the two-tier system of education that gives liberal education to some and industrial training to others. "Industrial training in this century should aim to give to the laborer not only professional efficiency but the meaning of his vocation, its historical import, and some comprehension of his position in the democratic society. .. . Out of this will arise an interest in the whole product which may lay the foundation for that intelligence which can in some measure resist the narrowing influence of the specialized labor in the factory. . . American industrial education must be a liberal education" (1908-9b, p. 157; $1908-9 c$, p. 213).

And last, but not least, the success of reform depends on tapping the vast resources of science. The traditional reliance on charity and philanthropy is no longer adequate to the task in hand. A path to contemporary reform is a "path from impulsive charity to social reconstruction"; to be 
successful, it has to lead "not only to efforts of amelioration but also to judgments of value and plans for social reforms" (1964, p. 399). Members of the academic community can make a large contribution to charting the reform program and formulating the means of social reconstruction. This is not simply because university professors possess specialized knowledge but also because they combine scientifically trained intelligence with the knowledge of the problems of the community at large. "The university is not an office of experts to which the problems of the community are sent to be solved; it is a part of the comunity within which the community problems appear as its own" (1915, p. 351$)$. What sets scientific intelligence apart and makes its contribution to the reform process so signally important is its impartial character, its "disinterestedness in existing structures, social and intellectual, and willingness to continually reconstruct these substituting for them other structures at any point and to any extent" (MP b3 addenda, f16). A scientifically trained mind can rise above conflicting values and find a solution that reconciles disparate claims in the best interests of the community as a whole. In the search for a solution to the problem, scientific intelligence is likely to be guided not by a ready-made blueprint of a future society, "a vision given on the mount," but by the sense of the possible, a realistic account of available means, and a habit of dealing methodically and rationally with the problem at hand. This habit of impartiality does not mean that progressive scholars have no interest in the outcome, no values of their own; they are after all on the side of progress, and so, when their job is done, the old social order will be replaced with a new one that is more universal, rational, and humane: "The rational solution of the conflicts, however, calls for the reconstruction of both habits and values, and this involves transcending the order of the community. A hypothetically different order suggests itself and becomes the end in conduct. . . . It is a social order that includes any rational being who is or may be implicated in the situation with which thought deals. It sets up an ideal world, not of substantive things but of proper method" (1964, p. 404).

In summary, Mead's theory of the reform process stems from his belief, widely shared by the progressive reformers of his time, that a terrible gap separates contemporary American society from the Jeffersonian ideal of popular democracy, that capitalism and democracy are currently working at cross purposes, and that, unless a way is found to humanize laissezfaire capitalism, the future of democracy in America will be imperiled. One road to a more humane and equitable society lies in the institutionalization of revolution-the term by which Mead meant that radical reforms can be carried out within the constitutional framework of democracy and that social reconstruction must be an ongoing concern rather than an all-out, one-time effort to set up a perfect society. Mead refused 
to spell out the exact nature of the future social order aside from general statements that it should be based on public good, take account of the interests of all social groups, and broaden the scope of economic and social opportunity for disadvantaged members of the community. $\mathrm{He}$ focused, instead, on methods and means of social reconstruction, the most salient of which are the mobilization of the general public, continued attention of the press, arbitration of labor-management disputes, the fusion of academic and vocational education, and the participation of members of the academic community. There was no gap between Mead's rhetoric and practical action. Whether he was marching with Jane Addams on the streets of Chicago in support of women's suffrage, surveying the homes of immigrants from eastern Europe, writing editorials on the dispute between the Board of Education and the Chicago Teachers' Federation, giving public support to the beleaguered reformers at the University of Wisconsin, or serving on the citizens' committee investigating labor grievances in the Chicago garment workers' strike-he was doing exactly what he thought a member of the public should do to stay politically engaged and to further the cause of reform. The interplay between Mead's political beliefs and his other intellectual pursuits was great indeed, and it comes into clear relief in his philosophical and social theory.

\section{SOCIALIZING HUMAN INTELLIGENCE: MEAD'S THEORY OF THE SOCIAL PROCESS}

The parallels between pragmatist and progressivist thought have been frequently noted (White 1957; Featherstone 1972; Levine 1969; Cremin 1969; Shalin 1986a), yet their implications have not been fully spelled out. My argument in the present section is that there is a far-reaching elective affinity between Progressivism and pragmatism, particularly the social pragmatism of Dewey and Mead. Indeed, the pragmatist vision of the world-in-the-making - the world that is perennially indeterminate, continuously emergent, and wonderfully malleable-is a metaphysics tailor-made for the age of reform. The traditional world of rationalist thought, the world of natural law and order, left little room for conscious efforts to make it more rational and humane. In contrast, the world confronting pragmatists was crying out for reform; it had to be transformed, and not just by the impersonal forces of evolution but by human intelligence. The latter, according to pragmatist philosophers, was not a mirror faithfully reflecting natural laws but an active force capable of transforming matter according to a logic of its own. Nowhere is the transformative, constitutive power of reason more evident or urgently needed than in the social domain: "In the physical world we regard ourselves as standing in some degree outside the forces at work, and thus 
avoid the difficulty of harmonizing the feeling of human initiative with the recognition of series which are necessarily determined. In society we are the forces that are being investigated, and if we advance beyond the mere description of the phenomena of the social world to the attempt at reform, we seem to involve the possibility of changing what at the same time we assume to be necessarily fixed" (Mead 1899a, pp. 370-71). It seems logical, therefore, that, to make room for reform, pragmatists would postulate a measure of indeterminacy, that they would proclaim that "uncertainty does not belong simply to the values, it belongs to the facts as well" (MP b8, f1), that they would urge that "the individual and environment-the situation-mutually determine each other" (Mead [1908] 1964, p. 86). If one were to assert the possibility of reform, one had to decry the morality that pictured the existing order of things as inherently rational and to replace it with a new ethics, according to which "moral advance consists not in adapting individual natures to the fixed realities of a moral universe, but in constantly reconstructing and recreating the world as the individuals evolve" (Mead [1908] 1964, p. 90). These philosophical tenets found their expression in the pragmatism-inspired (interactionist) theory of society.

In one of the posthumously published volumes of Mead's works appears a telling passage in which he formulates the central problem of modern society: "How can you present order and structure in society and bring about the changes that need to take place, are taking place? How can you bring those changes about in orderly fashion and yet preserve order? To bring about change is seemingly to destroy the given order, and yet society does and must change. That is the problem, to incorporate the methods of change into the order of society itself" (1936, pp. 361-62). This question is paradigmatic to the conception of sociology as the science of social reconstruction or the science of social control that gained wide currency among American sociologists in the Progressive Era (Faris 1967; Fisher and Strauss 1978; Janowitz 1978; Shalin 1986a). It was commonly held at the time that sociology dealt with the problems of society undergoing social transformation, that the "process of reconstructing social conditions is the process with which the social sciences deal" (MP b7, f8). It was also widely assumed that sociology could aid in efforts to minimize the more disruptive consequences of social change. Indicative of the community of assumptions underlying sociological thinking of this period was the concept of social control. This was more than a technical term; it can also be seen as a theoretical expression of progressive ideology. How can we exercise intelligent control over social processes? was the burning question of the Progressive Era, and it was in response to this query that sociologists came up with an ingenuous answer: Intelligent control over human society requires social control over human intelligence. What this 
meant was that the fortunes of society did not have to be decided on the barricades and in the flames of revolutions, for the real battle was for people's minds. To influence the direction in which society grows, one had to reform or, what is the same, to inform the consciousnesses of its members. That is to say, the answer to the modern predicament was not coercion and violence but social control. This answer, along with other precepts of social interactionism, was consistent with the political climate of the age of reform. Once again, Mead's writings offer us insight into the interplay between ideological beliefs and substantive theorizing in the Progressive Era.

As we have seen before, Mead fully acknowledged the socialists' role in exposing capitalism's seedier sides and raising the workers' awareness of the need to fight for their rights. There was one more, and not so obvious, thing for which Mead was ready to credit socialism-its role in striking down the then prevalent concept of man as an asocial being. In addition to exposing the economic institutions of laissez-faire capitalism, the socialist critique exposed its ideological fallacies, including the utilitarian idea of mind as biological endowment and of action as an instrument for maximizing personal pleasure. Socialist thinkers resolutely rejected this utilitarian view, substituting for it the idea of the inescapably social nature of man: "But the essence of man is no abstraction inherent in each separate individual. In its reality it is the ensemble (aggregate) of social relations" (Marx [1846] 1963, p. 198). Now Mead was not familiar with all the sociologically relevant works of Marx, certainly not with the writings of the young Marx, which appeared in print for the first time after Mead's death, yet he had an acute sense of socialism's sociological import. Socialist teaching is ultimately concerned with socializing man's action and thought, argued Mead: "Its reality lies in the essentially social character of all conduct, and the gospel, according to socialism, is the recognition that all self-seeking has and must have a social end, if it belongs inside a social organism. What society is struggling to accomplish is to bring this social side of our conduct out so that it may, in some conscious way, become the element of control" $(1899 \mathrm{~b}, \mathrm{p}$. 406). This insight, maintained Mead, is socialism's most useful contribution to the diagnosis of modern conditions.

Indeed, as long as our motives remain private and we act without regard for other members of society, democracy will continue to breed injustice and human misery. It is only when the individual takes into account the larger social context, when he "takes the role of the other," that social control becomes a guiding force in society and democracy realizes its true potential as a political system: "Social control depends, then, upon the degree to which the individuals in society are able to assume the attitudes of the others who are involved with them in common 
endeavor" (Mead [1924-25] 1964, p. 291). This, according to Mead, is the sociological essence of socialism, and this, I should add, is where his own sociological ideas intersect with those of the young Marx. Mead's premise that "the whole nature of our intelligence is social to the very core" (1934, p. 141) is consistent with Marx's view that "activity and mind, both in their content and in their mode of existence, are social, social activity and social mind" [1844] 1964, p. 138). The same is true of Mead's (1935-36, p. 70) contention that "the individual is no thrall to society. He constitutes society as genuinely as society constitutes the individual," which reminds us of Marx's (1964, p. 137) motto, “Just as society produces man as man, so is society produced by him." There is a family resemblance between Mead's assertion that "the unity and structure of the complete self reflects the unity and structure of the social process as a whole" (1934, p. 144) and Marx's thesis that "man, much as he may therefore be a particular individual, . . . is just as much a totality - the ideal society-the subjective existence of thought and experienced society for itself" (1964, p. 138). And, finally, Mead's (1934, p. 309) insight that the "relations between social reconstruction and self or personality reconstruction are reciprocal and internal" reflects the same dialectical pattern that is embedded in Marx's idea of revolutionary practice as "the coincidence of changing of circumstances and of human activity or self-changing" (1963, p. 198).

It would be a mistake to push the parallels between Mead and Marx too far. It would be equally mistaken to ignore them. These parallels are not spurious; they reflect the same determination to overcome the opposition between public and private, social and individual, society and man, the determination to bring into one continuum mind, self, and society that marked the thought of the young Marx and Mead. I wish to stress that Mead's interactionism is closest to Marx's romanticism, that is, to that early period in Marx's intellectual career when he was close to the idealism of Hegel and Fichte, when he did not yet break with bourgeois democratism and still had high regard for the curative powers of selfconscious reason (Gouldner 1973, pp. 337-40; Shalin 1986b, pp. 112-13). As Marx became increasingly disillusioned with the prospects for the peaceful transformation of society, the romantic-idealist themes gave way in his writings to a new emphasis on economic factors and revolutionary force. Mead, on the other hand, like most progressive thinkers, retained his youthful idealism as well as his romantic organicism with its root metaphor of man-the-microcosm (Shalin 1984, pp. 55-58). The most remarkable thing about romantic organicism is that it compels one to see man and society not as opposed entities but as aspects of the same process of the production of social reality as objective and meaningful. The individual appears here not just as one organ or part of the social whole but as a social self, or, to use the language of romantic organicism, a "species 
being" reflecting in unique fashion the totality of social relations. By the same token, society loses in this scheme its externality and thinglike character; it is dissolved into a series of interactions in the course of which it is continuously regenerated as a social universe, or universe of discourse. It is very important from the interactionist standpoint that the individual embraces within his self the whole of society, that he "takes the attitude of the generalized other." It is equally important that the individual does not become a passive receptacle of social norms and values but develops a critical attitude toward his social self and the society that provided him with this self. ${ }^{14}$ The individual is both "Me" and "I"-a responsible member of various social groups and a unique personality capable of transcending a given order, a law-abiding citizen and a critic of society.

Insofar as the individual successfully integrates these two aspects of his social existence, the relationship between the individual and society can be judged organic, which is exactly what progressives wished it to be. Here is a sample of statements expressing this romantic theme, as formulated by different progressive thinkers:

The organization and unification of a social group is identical with the organization and unification of any one of the selves arising within the social process. ... Each individual self within this process, while it reflects in its organized structure the behavior pattern of that process as a whole, does so from its own particular or unique standpoint. . . . [Mead 1934, pp. $144,201]$

But human society represents a more perfect organism. The whole lives truly in every member, and there is no longer the appearance of physical aggregation, or continuity. The organism manifests itself as what it truly is, an ideal or spiritual life, a unity of will. If then, society and the individual are really organic to each other, then the individual is society concentrated. $\mathrm{He}$ is not merely its image or mirror. He is the localized manifestation of its life. [Dewey 1969, p. 237]

A national structure which encourages individuality as opposed to mere particularity is one which creates innumerable special niches, adapted to all degrees and kinds of individual development. The individual becomes a nation in miniature, but devoted to loyal realization of a purpose peculiar to himself. The nation becomes an enlarged individual whose special purpose

14 "Human society, we have insisted, does not merely stamp the pattern of its organized social behavior upon any one of its individual members, so that this pattern becomes likewise the pattern of the individual's self; it also, at the same time, gives him a mind. . . . And his mind enables him in turn to stamp the pattern of his further developing self (further developing through his mental activity) upon the structure or organization of human society, and thus in a degree to reconstruct and modify in terms of his self the general pattern of social or group behavior in terms of which his self was originally constituted" (Mead 1934, p. 263). I have examined elsewhere (Shalin 1978) the macrosociological implications of this thesis. 
is that of human amelioration, and in whose life every individual should find some particular but essential functions. [Croly 1909, p. 414]

These utterances should not be taken to mean that progressives saw contemporary American society as an actual embodiment of organic interaction. A contemporary industrial society, as Mead (1934, p. 307) and other progressives repeatedly stated, is ridden with contradictions: "Within such a society, conflicts arise between different aspects or phases of the same individual self . . . as well as between individual selves [that must be] settled or terminated by reconstructions of particular social situations, or modifications of the given framework of social relations, wherein they arise or occur." Rather, the above statements should be seen as an attempt to lay down a standard for judging contemporary reality, an ideal and a theory that indicated the direction of social reconstruction and the method of social control. As an ideal, the future society envisioned by the progressive imagination was somewhat akin to the romantic notion of gemeinschaft, in that it accentuated the virtues of the "Great Community," "free and enriching communion," or free intercourse, whose participants are "the constant makers of a continuously new society" (Dewey [1927] 1954, p. 115-17; [1929] 1962, p. 143). A formal model of this future society was "the universe of discourse, a community based simply on the ability of all individuals to converse with each other through use of the same significant symbols"; its actualization requires an understanding that "the brotherhood of men . . . is the basis for a universal society" (Mead 1934, pp. 282-83). As a method, interactionist theory extolled the advantages of intelligent social control over violent means of effecting social change. Its preference for peaceful, noncoercive forms of social reconstruction was already implied in its basic premises: If mind, self, and society belong to one continuum and are indeed aspects of the same social intercourse, then the reconstruction of society is largely a matter of reconstructing the human mind. "An institution is, after all, nothing but an organization of attitudes which we all carry in us" (Mead 1934, p. 211), and so, abolishing obsolete institutions means reforming our attitudes, our ways of thinking. That is, to change society, we have to change ourselves: "Thus the relation between social reconstruction and self or personality reconstruction by the individual members of any organized human society entails self or personality reconstruction in some degree or other by each of these individuals. . . . In both types of reconstruction the same fundamental material of organized social relations among human individuals is involved, and is simply treated in different ways, or from different angles or points of view, in the two cases respectively; or in short, social reconstruction and self or personality reconstruction are the two sides of a single process-the process of human social evolution" (Mead 1934, p. 309). 
To sum up, there is an elective affinity between Mead's social philosophy and his political beliefs. Along with other pragmatists, Mead abandoned the rationalist universe of natural order, replacing it with a world brimming with possibilities and open to social reform. Translated into the language of sociological theory, this world-in-the-making yielded a peculiar version of "sociological progressivism" (Fisher and Strauss 1978, p. 488), with its dynamic picture of society as ongoing social interaction. Every individual appears in this picture as simultaneously a product and producer of society, whereas society transpires as both an antecedent and outcome of social interaction. Mind, self, and society are bound together here as parts of one continuum, or aspects of the same process of production, of social reality as objective and meaningful, which makes it imperative that each be understood in terms of the other. The circle involved in the interactionist mode of reasoning is not unintentional; it is the dialectical or hermeneutical circle that requires that the part be explained through the whole and the whole in terms of its parts. This dialectical approach, characteristic of 19th-century romanticism and 20th-century Progressivism, accentuates the possibility of peaceful social transformation and predicates the reconstruction of society on the reconstruction of the human mind. The ultimate goal of social reconstruction, as envisioned in social interactionism, is a democratic community based on the ideal of free discourse or organic interaction (Habermas 1981, pp. 11-68). When the self-consciousness of all individuals is so altered that each can rejoice with the successes, empathize with the miseries, and help meet the needs of others, that is, when everyone assumes the attitude of the whole society, then the latter is transformed into a truly universal and democratic community.

\section{CONCLUSION: MEAD AND THE PROGRESSIVE LEGACY}

Many observers have commented on the contradictions inherent in the Progressive movement, on its "profound internal dialectic" (Conn 1933, p. 1; see also Hofstadter 1955, pp. 5, 236; White 1957, p. 46; Noble 1958). There is indeed a great deal of tension in progressive ideology. Its adherents extolled the virtues of entrepreneurial individualism and at the same time stressed the need for public control; they longed for a socialism of opportunity yet defended the capitalism of property; they urged a radical break with the present and reached deep into the past for an ideal of the future; above all, they were determined to escape the twin dangers of radicalism and conservatism. "There is the conflict between the old and the new, between the radical and the conservative," wrote Mead about the dominant mood of this time, "but . . . we may not wish to be either 
radical or conservative. We may wish to comprehend and to do justice to the changing valuations" $(1938$, p. 480). It is this desire to rise above the political extremes of the Right and the Left that brought on the scorn for the progressives from some contemporary and modern critics. Those on the Right have charged that Progressivism ultimately leads to socialism. For critics on the Left, Progressivism has been little more than an episode in the ongoing effort to stem the inexorable decline of corporate capitalism. Yet historical Progressivism defies all attempts to subsume it under a neat ideological label.

Progressive reformers were democrats of a new breed. These were "men and women longing to socialize their democracy" (Addams 1910, p. 116), working for "a more balanced, a more equal, even, and equitable system of human liberties" (Dewey 1946, p. 113) and determined "to limit and control private economic power as the Founders had limited political power" (Graham 1967, p. 5). It is arguable whether, as Scott (1959, pp. 697, 690) claims, "the Progressive Era was more original than the New Deal and more daring as well," but he is right when he stresses its historical importance, and he is justified in his critique of persistent attempts in modern historiography "to conservative Progressivism." Kolko's thesis (1963) that progressive reforms constituted "the triumph of conservatism" flies in the face of the progressives' democratic aspirations. The very term "social reconstruction" adopted by progressives was indicative of their values. It harked back to the Civil War era, when Lincoln first invoked it to describe the need to break cleanly with the past and to start the country on a radically new path. With an equal sense of urgency, progressives faced up to the task of social reconstruction, which on the eve of the 20th century meant bringing government into the marketplace, broadening the scope of economic opportunity, democratizing education, and transforming the public into an agent of social control. Although far from a monolithic movement, Progressivism was championed by the people who, regardless of their many differences, shared the belief that the key to the transformation of society is to be found in public discourse rather than in the skills of professional politicians. In their fight against laissez-faire capitalism, progressives borrowed many an insight from socialism; some claimed that "we are in for some kind of socialism, call it by whatever name we please" (Dewey 1962, p. 119). Nevertheless, there were important points of theory and method on which progressives and socialists parted company. Progressives endorsed socialism's emancipatory goals but rejected its revolutionary means. Their attempt, unsuccessful as it might have been, to work out a scheme for securing these goals without breaking the constitutional framework of democracy-an attempt that is at the core of the progressive agenda-is the most enduring legacy of the 
Progressive movement. It is also a source of perennial tension and contradiction in Progressivism as well as in the kindred pragmatist and interactionist movements.

Progressives recognized that democracy would self-destruct unless it provided room for justice, that society must secure minimum economic and social standards for every one of its members. But how much democracy? How much justice? Does it include socialized medicine, guaranteed employment, free college education? Both Mead and Dewey were likely to include these among the standards of social decency necessary for the development of each individual's creative potential, but there is nothing in progressive ideology that would help to resolve this matter in principle. More important, one has to wonder whether full equality of opportunity can be accomplished under private ownership of the means of production. The critics on the Left had good reason to doubt that the efforts of the progressives to socialize opportunity would ever bring about the socialism of opportunity in a capitalist America. The socialists' wholesale dismissal of Progressivism, however, was far too hasty. They did not understand the progressives' preoccupation with the means of social reconstruction and specifically with their concern for the fate of democracy in a society where economic power was radically centralized. The highest value for socialists was economic equality; once it was achieved, Marx thought, human rights would take care of themselves, and universal democracy would naturally ensue. But more recent socialist thinkers have become increasingly aware (Lynd 1974, p. 773; Giddens 1981, pp. 172-73; Lukes 1985) that this outcome is far from assured. All radical attempts to nationalize the means of production in this century have resulted in the breakdown of democratic institutions: the more radical the scope of nationalization, the more deleterious effect it seems to have on human rights; the more successful the efforts to do away with bourgeois democracy, the less room left for radical social criticism. This is not to say that capitalism guarantees human rights (think of Chile or South Africa), only that human rights have invariably been a casualty of attempts to substitute a socialist (in Marx's sense of the word) for a capitalist society. In light of this historical experience, progressives' concern for democracy and the means-ends relationship in social reconstruction seems far from irrelevant. There is a dialectical tension between justice and democracy, equality and freedom, that is inherent in Western liberalism (Lasch 1983; Gutmann 1983) and that the progressives were nowhere close to resolving, but this is a creative tension, and progressives were correct in bringing it to light and stressing the need to balance the considerations of justice with those of democracy.

The amorphous notion of public good is another source of difficulty and confusion in progressive theory. Mead consistently refused to enunciate 
what he meant by "public good" or to spell out the values that would help one judge a policy or a program as being in the "interests of the community as a whole." Like other reformers of his time, he was confident that each contentious issue lends itself to public adjudication and that every social conflict could be amicably resolved. Critics have been attacking the excessive optimism, deliberate ambiguity, and opportunistic tendencies in pragmatist and progressive thought for a long time (Bourne 1915; Smith 1931; Niebuhr [1932] 1960; Novack 1975). What they are less likely to see is that these tendencies are not without a rationale. Pragmatists and progressives refused to specify the exact nature of a future democratic society because they believed that "every generation has to accomplish democracy over and over again," that "the very idea of democracy . . . has to be constantly discovered, and rediscovered, remade and reorganized" (Dewey 1946, pp. 31, 47). Any overarching scheme, "a vision given on the mount," is likely to turn into a straitjacket if followed rigidly and unswervingly, as numerous attempts in recent decades to impose a shining revolutionary ideal on an unyielding reality readily testify. It is not true that progressives had no vision of the future or that all their values were ad hoc. The failure of the progressives to endorse the comprehensive social security program, caused by their fear-again not entirely misplaced, as seen from the vantage point of the present-of irresponsible patronage politics and unwieldy federal bureaucracy, does not undermine their commitment to spreading social justice. Their emphasis on regulatory reforms and public control instead of state-run and government-supervised programs, although unquestionably too limiting even for their time, was also far from disingenuous and class-motivated, as it is sometimes portrayed. Progressives were essentially right in leaving it to the public to define and redefine continuously what shape their ideal of a more democratic and humane society should assume in a given historical setting. There will always be much bickering and plenty of mistakes made, but in the long run a public forum is the best one for articulating the public good. The idea of a democratic public, as Janowitz (1952, 1978) rightly points out, that is, the idea of "the passing of functions which are supposed to inhere in the government into activities that belong to the community" (Mead 1899a, p. 369), is an enduring contribution of pragmatism and interactionism to contemporary social thought.

Another facet of philosophical and sociological progressivism that has drawn criticism is tied to the belief in scientific method as an instrument of social reform. Mead's insistence that "scientific method . . . is nothing but a highly developed form of impartial intelligence," that "science has become the method of social progress, and social progress itself has become a religion" ([1923] 1964 , p. $256 ; 1918$, p. 639) is bound to raise a number of critical questions. Charges of scientism and positivism are 
frequently leveled against pragmatism in this connection (Selsam 1950). Much of this criticism, in my view, stems from a misconception of the pragmatist idea of science. It is not true that pragmatists saw scientific knowledge as being value neutral and scientists as standing above society. "Knowing, including most emphatically scientific knowledge," stressed Dewey (1946, p. 17), "is not outside social activity, but is itself a form of social behavior, as much as agriculture or transportation." Moreover, as Mead ([1930] 1964, p. 406) indicated, "It is not until science has become a discipline to which the research ability of any mind from any class in society can be attracted that it can become rigorously scientific." Pragmatists did not seek value neutrality, nor did they espouse value partisanship. Their position is best described as value tolerance, in that it advocates "taking the value perspective of the other" and seeks truth at "the intersection of conflicting values" (Shalin 1979, 1980). ${ }^{15}$ Mead and the pragmatists did not trust the magic powers of scientific intelligence to resolve the burning issues of the day. Rather, they valued science as a form of rational discourse in which every participant has a say, all claims are subject to testing, and each solution undergoes continuous revision. It is certainly not a perfect institution, but, warts and all, science offers the best available model of democracy in action, and we should credit pragmatists for focusing attention on the operations of value-tolerant science and the contribution it could make to rational discourse in society at large.

One final issue that needs to be addressed here concerns the progressives' boundless trust in democratic institutions and peaceful revolution in America. As many critics (Bates 1933; Selsam 1950; Purcell 1973; Schwedinger and Schwedinger 1974; Karier 1975; Novack 1975) have argued-correctly-pragmatists tended to exaggerate both the potential for and the actual extent of social change in America. They tended to confuse the normative and the descriptive in their accounts by, on the one hand, criticizing contemporary democracy and, on the other, insisting that the institutional framework of democracy necessary for social reconstruction was already in place. This confusion is clearly visible in the almost total blindness of Mead and most of the progressives to the plight of blacks. They spoke eloquently on behalf of immigrants, women, and

${ }^{15}$ There is an interesting parallel between the way pragmatists and contemporary German scholars searched for a proper mix of science and ethics. Thus, both Dewey and Weber expressed considerable regard for scientific procedures, both thought that objective knowledge is grounded in values, and both rejected the "ethic of ultimate ends" and opted for the "ethics of responsibility" or "ethics of means." Ultimately, however, Weber praised value neutrality as a stance befitting scientific workers, whereas Dewey and the pragmatists were more in tune with the idea of value tolerance. 
children, but the institutionalized exclusion of blacks from American democracy did not seem to bother progressive reformers much. It should be also emphasized that Mead, along with other progressives, held a rather naive view of business leaders' readiness to heed the voice of reason and jump on the bandwagon of reform. "While a good part of the program of socialism is being put into practice," wrote Mead (MP b2 addenda, f27), "the striking difference lies in the fact that it [is] being undertaken not by the proletariat but by the whole community under the eager guidance of captains of industry, community generals, research scientists and conservative statesmen." This statement flies in the face of the long war with trade unions and dogged opposition to labor reforms that "captains of industry" waged (as they still do), using more or less preposterous excuses. It took a large-scale rebellion at Homestead and elsewhere to convince big business that reforms were unavoidable and useful after all. And we may add that it took a massive campaign of civil disobedience in the 1960s to bring blacks into American democracy. All of which suggests that American society, certainly in the Progressive Era, was far from the institutional democracy in which revolution could have been carried out by legal means alone. Having said this, I take issue with those critics who see pragmatists and progressives as dreamy idealists at best and apologists for corporate capitalism at worst. "These men were progressives and meliorists of their day, but they were realists and skeptics as well" (Janowitz 1970, p. xii). They fought hard battles in Congress for progressive legislation, they were doing tangible things to improve the lot of immigrants and the poor, and they were prepared to change the very system if necessary to make room for meaningful reform: "In order to endure under present conditions, liberalism must become radical in the sense that, instead of using social power to ameliorate the evil consequences of the existing system, it shall use social power to change the system" (Dewey 1946, p. 132). There is every reason to believe that Mead would have endorsed this statement.

\section{REFERENCES}

Aaron, D. 1951. Men of Good Hope: A Story of American Progressives. New York: Oxford University Press.

Addams, Jane. 1902. Democracy and Social Ethics. New York: Macmillan. 1910. Twenty Years at Hull-House. New York: Macmillan.

Barnard, John. 1969. From Evangelicalism to Progressivism at Oberlin College, 18661917. Columbus: Ohio State University Press.

Bates, E. S. 1933. "John Dewey: America's Philosophic Engineer." Modern Monthly 7:387-96.

Bliss, W. D. P. (1890) 1970. "What to Do Now?" Pp. 350-54 in Socialism in America: From the Shakers to the Third International, edited by Albert Fried. Garden City, N.Y.: Doubleday. 
Bourne, R. S. 1915. “John Dewey's Philosophy." New Republic 13:154-56.

Castle, Henry N. (1889) 1902. "Letter of Henry Castle to George H. Mead, February 3, 1899," pp. 578-81 in Henry Northrup Castle: Letters. London: Sands.

- 1902. "Letter of Henry Castle to Mabel, Helen, and Mother, November 27, 1894." Pp. 783-85 in Henry Northrup Castle: Letters. London: Sands.

Conn, Peter. 1983. The Divided Mind: Ideology and Imagination in America, 18981917. Cambridge: Cambridge University Press.

Cremin, L. A. 1969. "John Dewey and the Progressive Education Movement." Antioch Review 67:160-73.

Croly, Herbert. 1909. The Promise of American Life. New York: Macmillan.

Debbs, Eugene. 1912. "Sound Socialist Tactics." International Socialist Review 12:481-86.

Deegan, M. J., and J. S. Burger. 1978. "George Herbert Mead and Social Reform: His Work and Writings." Journal of the History of the Behavioral Sciences 14:36273.

Dewey, John. (1888) 1969. "The Ethics of Democracy." Pp. 227-49 in John Dewey, the Early Works, 1882-1889, vol. 1. Carbondale: Southern Illinois University Press.

-. (1927) 1954. The Public and Its Problems. New York: Holt.

- (1929) 1962. Individualism, Old and New. New York: Capricorn.

. (1938) 1950. "What I Believe, Revised." Pp. 32-35 in Pragmatism and American Culture, edited by Gail Kennedy. Boston: Heath.

. 1946. The Problems of Men. New York: Philosophical Library.

Dewey, John, and John L. Childs. 1933. "The Underlying Philosophy of Education." Pp. 287-319 in The Educational Frontier, edited by W. H. Kilpatrick. New York: Appleton-Century.

Diner, S. J. 1975. "Department and Discipline: The Department of Sociology at the University of Chicago, 1892-1920." Minerva 13:514-53.

- 1980. A City and Its Universities, Public Policy in Chicago, 1892-1919. Chapel Hill: University of North Carolina Press.

Editorial. 1882. Oberlin Review 10:55. 1883. Oberlin Review 10:175-76.

Faris, Robert E. 1970. Chicago Sociology, 1920-1932. Chicago: University of Chicago Press.

Featherstone, J. 1972. "John Dewey." New Republic 8:27-32.

Fisher, Berenice M., and Anselm L. Strauss. 1978. "Introduction." Pp. 457-98 in A History of Sociological Analysis, edited by Tom Bottomore and Lewis A. Coser. New York: Basic.

Fried, Albert, ed. 1970. Socialism in America: From the Shakers to the Third International. Garden City, N.Y.: Doubleday.

Furner, Mary O. 1975. Advocacy \& Objectivity. A Crisis in the Professionalization of American Social Sciences, 1865-1905. Lexington: University Press of Kentucky.

George, Henry. (1879) 1926. Progress and Poverty. New York: Doubleday, Page.

Giddens, Anthony. 1981. A Contemporary Critique of Historical Materialism, vol. 1. Berkeley and Los Angeles: University of California Press.

Goldman, Eric. 1956. Rendezvous with Destiny: A History of Modern American Reform. New York: Vintage.

Gouldner, Alvin A. 1973. "Romanticism and Classicism: Deep Structures in Social Science." Pp. 323-66 in For Sociology: Renewal and Criticism in Sociology Today, by Alvin A. Gouldner. New York: Basic.

Graham, Otis L. 1967. An Encore for Reform: The Old Progressive and the New Deal. New York: Oxford University Press.

Gutmann, Amy. 1983. "How Liberal is Democracy?" Pp. 25-50 in Liberalism Reconsidered, edited by Douglas MacLean and Claudia Mills. Totowa, N.J.: Rowman \& Allanheld. 
Habermas, Jürgen. 1981. Theorie des Kommunikativen Handelns. Band 2. Frankfurt: Suhrkamp.

Hofstadter, Richard. 1955. The Age of Reform: From Byron to FDR. New York: Knopf.

Janowitz, Morris. 1952. The Community Press in an Urban Setting. Chicago: University of Chicago Press.

- 1970. "Preface." Pp. xi-xii in Introduction to the Science of Sociology, by Robert Park and Ernest W. Burgess. Chicago: University of Chicago Press.

- 1978. The Last Half-Century: Societal Change and Politics in America. Chicago: University of Chicago Press.

Joas, Hans. 1985. G. H. Mead: A Contemporary Reexamination of His Thought. Cambridge: Polity.

Karier, C. J. 1975. "John Dewey and the New Liberalism." History of Education Quarterly 15:417-43.

Kolko, Gabriel. 1963. The Triumph of Conservatism: A Reinterpretation of American History, 1900-1916. New York: Free Press.

Lasch, Christopher. 1983. "Liberalism in Retreat." Pp. 105-16 in Liberalism Reconsidered, edited by Douglas MacLean and Claudia Mills. Totowa, N.J.: Rowman \& Allanheld.

Laslett, John H. M., and Seymour Martin Lipset, eds. 1974. Failure of a Dream? Essays in the History of American Socialism. Garden City, N.Y.: Anchor.

Levine, D. 1969. "Randolph Bourne, John Dewey, and the Legacy of Liberalism." Antioch Review 29:234-44.

Lukes, Steven. 1985. Morality and Marxism. London: Oxford University Press.

Lynd, Staughton. 1974. "The Prospects of the New Left." Pp. 713-38 in Failure of a Dream? Essays in the History of American Socialism, edited by John H. M. Laslett and Seymour Martin Lipset. Garden City, N.Y.: Anchor.

McNaught, Kenneth. 1974. "Comment." Pp. 409-20 in Failure of a Dream? Essays in the History of Socialism in America, edited by John H. M. Laslett and Seymour Martin Lipset. Garden City, N.Y.: Anchor.

Marx, Karl. (1844) 1964. The Economic \& Philosophic Manuscripts of 1844. New York: International.

. (1846) 1963. The German Ideology. Parts 1 and 3. New York: International.

Mead, George H. (n.d.) George Herbert Mead Papers. University of Chicago Archives.

—. 1881. "The Relation of Art to Morality." Oberlin Review 9:63-64.

. 1882 a. "Charles Lamb." Oberlin Review 10:15-16.

1882 b. "De Quincey." Oberlin Review 10:50-52.

. 1882c. "John Locke." Oberlin Review 10:217-19.

1884. "Republican Persecution, Letter to the Editor." Nation 39:519-20.

1899a. "The Working Hypothesis in Social Reform." American Journal of Sociology 5:367-71.

. 1899b. "Review of Le Bon, Psychology of Socialism." American Journal of Sociology 5:404-12.

- 1907. "Review of Jane Addams's The Newer Ideals of Peace." American Journal of Sociology 13:121-28.

. (1908) 1964. "The Philosophical Basis of Ethics." Pp. 82-93 in Selected

Writings: George Herbert Mead, edited by A. J. Reck. New York: Bobbs-Merrill.

. 1907-8. "The Educational Situation in the Chicago Public Schools." City Club Bulletin 1:131-38. 19-20.

-1908-9a. "Industrial Education, the Working Man, and the School." Elementary School Teacher 9:369-83. 
- 1908-9b. "Editorial Notes." Elementary School Teacher 9:156-57.

- 1908-9c. "Editorial Notes." Elementary School Teacher 9:212-14.

1909. "The Adjustment of Our Industry to Surplus and Unskilled Labor."

Proceedings of the National Conference of Charities and Corrections 34:222-25.

- 1912. "Remarks on Labor Night concerning Participation of Representatives of Labor in the City Club." City Club Bulletin 5:9.

1915. "Madison: The Passage of the University of Wisconsin through the State

Political Agitation of 1914; the Survey by William H. Allen and His Staff and the

Legislative Fight of 1915, with the Indications These Offer of the Place the State

University Holds in the Community." Survey 35:349-61.

- (1915) 1964. "Natural Rights and the Theory of the Political Institution." Pp.

150-70 in Selected Writings: George Herbert Mead, edited by A. J. Reck. New

York: Bobbs-Merrill.

1916-17. "Professor Hoxie and the Community." University of Chicago Magazine 9:114-17.

. 1917a. "Germany's Crisis-Its Effect on Labor. Part I." Chicago Herald, Thursday, July 26.

. 1917b. "Germany's Crisis-Its Effect on Labor. Part II." Chicago Herald, Friday, July 27.

August 2 .

1917c. "War Issues to U.S. Forced by Kaiser." Chicago Herald, Thursday,

. 1917 d. "Democracy's Issues in the World War." Chicago Herald, August 4. . 1917e. "American Ideals and the War." Chicago Herald, Friday, August 3. 1918. "Social Work, Standards of Living and the War." Proceedings of the National Conference of Social Work 45:637-44.

- (1923) 1964. "Scientific Method and the Moral Sciences." Pp. 248-66 Selected

Writings: George Herbert Mead, edited by A. J. Reck. New York: Bobbs-Merrill. (1924-25) 1964. "The Genesis of the Self and Social Control." Pp. 267-93 in

Selected Writings: George Herbert Mead, edited by A. J.Reck. New York: BobbsMerrill.

(1925-26) 1964. "The Nature of Aesthetic Experience." Pp. 294-305 in Selected Writings: George Herbert Mead, edited by A. J. Reck. New York: BobbsMerrill.

. (1930) 1964. "Philanthropy from the Point of View of Ethics." Pp. 392-407 in Selected Writings: George Herbert Mead, edited by A. J. Reck. New York: BobbsMerrill.

1934. Mind, Self, and Society. Chicago: University of Chicago Press.

. 1935-36. "The Philosophy of John Dewey." International Journal of Ethics 46:64-81.

- 1936. Movements of Thought in the Nineteenth Century. Chicago: University of Chicago Press.

1938. The Philosophy of the Act. Chicago: University of Chicago Press.

Niebuhr, Reinhold. (1932) 1960. Moral Man and Immoral Society. New York: Scribners.

Noble, David W. 1958. The Paradox of Progressive Thought. Minneapolis: University of Minnesota Press.

Novack, George. 1975. Pragmatism versus Marxism. New York: Pathfinder.

Orloff, Ann Shola, and Theda Skocpol. 1984. "Why Not Equal Protection? Explaining the Politics of Public Social Spending in Britain, 1900-1911, and the United States, 1880s-1920." American Sociological Review 49:726-50.

Pease, Otis, ed. 1962. The Progressive Years: The Spirit and Achievement of American Reform. New York: Braziller.

Purcell, Edward A., Jr. 1973. The Crisis of Democratic Theory. Lexington: University Press of Kentucky. 
Raushenbush, Winifred. 1979. Robert E. Park: Biography of a Sociologist. Durham, N.C.: Duke University Press.

Reck, A. J., ed. 1964. Selected Writings: George Herbert Mead. New York: BobbsMerrill.

Resek, Carl. 1967. The Progressives. Indianapolis: Bobbs-Merrill.

Roosevelt, Theodore. 1909. "Socialism." Outlook 41:619-23.

. (1912) 1962. "A Confession of Faith." Pp. 310-41 in The Progressive Years:

The Spirit and Achievement of American Reform, edited by Otis Pease. New York: Braziller.

Schwedinger, Herman, and Julia R. Schwedinger. 1974. The Sociologists of the Chair. New York: Basic.

Scott, A. M. 1959. "The Progressive Era in Perspective." Journal of Politics 21: $685-701$.

Selsam, Howard. 1950. "Science and Ethics." Pp. 81-92 in Pragmatism and American Culture, edited by Gail Kennedy. Boston: Heath.

Shalin, D. N. 1978. "The Genesis of Social Interactionism and Differentiation of Macro- and Microsociological Paradigms." Humboldt Journal of Social Relations $6: 3-38$.

- 1979. "Between the Ethos of Science and the Ethos of Ideology." Sociological Focus 12:275-93. $361-82$.

- 1984. "The Romantic Antecedents of Meadian Social Psychology." Symbolic Interaction 7:43-65.

L 1986a. "Pragmatism and Social Interactionism." American Sociological Review 51:9-29.

- $1986 b$. "Romanticism and the Rise of Sociological Hermeneutics." Social Research 53:77-123.

. 1987. "Socialism, Democracy and Reform: A Letter and an Article by George H. Mead." Symbolic Interaction, vol. 10, no. 2.

Smith, T. V. 1931. "The Social Philosophy of George Herbert Mead." American Journal of Sociology 37:368-85.

Smith, Timothy L. 1957. Revivalism and Social Reform in Mid-Nineteenth Century America. New York: Abington.

Sombart, Werner. (1909) 1968. Socialism and Social Movement. New York: Kelley. Wilson, Woodrow. (1912) 1962. "Address at Duquesne Garden." Pp. 372-78 in The Progressive Years: The Spirit and Achievement of American Reform, edited by Otis Pease. New York: Braziller.

White, Morton C. 1957. Social Thought in America: The Revolt against Formalism. Boston: Beacon. 